\title{
淡路島の漁港・港湾における南海トラフ巨大地震津波対策に関する検討
}

\section{A n Examination of Countermeasures at Fishery Ports and Harbors in Awaji Island against N ankai Trough Great Earthquake and Tsunami}

\author{
宇野宏司 ${ }^{1}$ ・瀬崎 瑛 $^{2} \cdot$ 辻本剛三 $^{3}$ ・柿木哲哉 ${ }^{4}$ \\ Kohji UNO, A kira SEZAKI, Gozo Tsujimoto and Tetsuya K AK INOK I
}

\begin{abstract}
The fishery is one of the core industries and many ports are put in place around Awaji Island. If Nankai Trough Great Earthquake happens in the near future, it is expected the coastal regions of Awaji Island will suffer serious tsunami damage. Central Disaster Prevention Council in Japan announced the anticipated damage from Nankai Trough Great Earthquake; however, the verification in detail hasn't been conducted yet. In this paper, we extract the present states and problems by hearing investigations for the managers and examine the characteristics of the anticipated tsunami damage such as submerged depth, temporal limitation of residents and ships by using the announced simulation results.
\end{abstract}

\section{1はじめに}

淡路島（図-1）は瀬戸内海国立公園の東端に位置し, その周囲は大阪湾, 播磨灘, 紀伊水道といった海域に囲 まれている. 同島では地形的に天然の入り江等に恵まれ なかったため, 古くから漁港整備が進められてきた. 現 在, 島内には19の漁協が点在しており, 漁港数22, 港湾 数16は，それぞれ県下の $41.5 \%, 53.3 \%$ 占めている（兵 庫県, 2012, 2013a・b). 淡路島の水産業は, 5t未満の小 型船による漁業と養殖業が中心であり，本島の地域経済 を支える重要な産業となっている。 これら漁港・港湾は 重要な社会インフラであり，近い将来に発生が予想され る南海トラフ巨大地震の際には, 到達する津波の特性を 把握し, 最大限の防災・減災効果が発揮できるよう対策 を講じておく必要がある.

南海トラフ巨大地震の発生の際の被害想定について は, 内閣府中央防災会議で検討がなされている（内閣府, 2012a）が, 同会議モデル検討会による試算結果の公表 值（内閣府，2012b）は市町レベルに留まっており，個々 の漁港・港湾を対象に詳しく調べた事例は少ない.

本研究では, 漁港・港湾管理者に対するヒアリング調 査によって淡路島の漁港・港湾における防災・減災対策 の現状と課題を明らかにするとともに, 内閣府の試算結 果を各漁港・港湾スケールで詳細に整理・解析し, 淡路 島沿岸に到達する津波の特性や被害予想, 避難や船舶沖 出しの猶予時間について検討した.

$\begin{array}{llll}1 & \text { 正会員 } & \text { 博(工) } & \text { 神戸市立工業高専准教授 } \\ 2 & \text { 正会 } & \text { 工学士 } & \text { 阪神高速技術(株) } \\ 3 & \text { フェロー } & \text { 工博 } & \text { 神戸市立工業高専教授 } \\ 4 & \text { 正会員 } & \text { 博(工) } & \text { 神戸市立工業高専教授 }\end{array}$

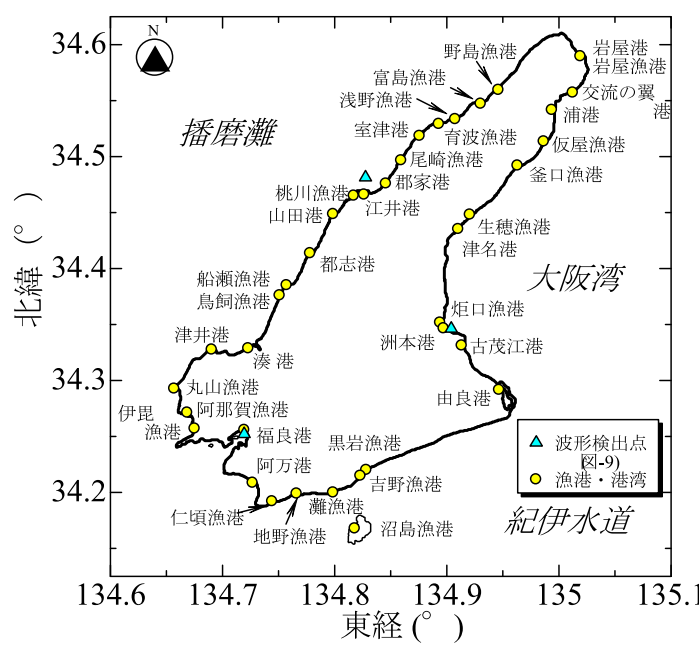

図-1 淡路島の漁港・港湾

\section{2 調查方法}

\section{(1) ヒアリング調査}

淡路島に点在する漁港・港湾における津波襲来時に備 えた現在の取り組みや, 将来に向けての対策を把握する ため，管理者である兵庫県庁漁港課，淡路県民局洲本土 木事務所港湾課及び漁港課においてヒアリング調査を実 施した（2012年8月）.

\section{(2) データ解析}

2012年8月に内閣府中央防災会議のモデル検討会によ る「南海トラフの巨大地震による津波高・浸水域等（第 二次報告)」が公表された（内閣府，2012a）。本研究で は, このモデル検討会による試算ケース（表-1）のうち, 淡路島沿岸に大きな影響をもたらすとされるケース03〜 05，07，10について，各漁港・港湾に該当する最小メッ 
表-1 内閣府による試算ケース

\begin{tabular}{l|l}
\hline ケース名 & \multicolumn{1}{|c}{ 内 容 } \\
\hline ケース01 & 駿河湾〜紀伊半島沖に大すべり域を設定 \\
\hline ケース02 & 紀伊半島沖に大すべり領域を設定 \\
\hline ケース03 & 紀伊半島沖〜四国沖に大すべり領域を設定 \\
\hline ケース04 & 四国沖に大すべり領域を設定 \\
\hline ケース05 & 四国沖〜九州沖に大すべり領域を設定 \\
\hline ケース06 & 駿河湾〜紀伊半島沖に大すべり域を設定+分岐断層 \\
\hline ケース07 & 紀伊半島沖に大すべり領域を設定+分岐断層 \\
\hline ケース08 & 駿河湾〜愛知県東部沖と三重県南部沖〜徳島県沖に大 \\
\hline すべ域を設定 \\
\hline ケース09 & 愛知県沖〜三重県沖と室戸岬沖に大すべり領域を設定 \\
\hline ケース10 & 三重県南部沖〜徳島県沖に大すべり領域を設定 \\
\hline ケース11 & 室戸岬沖と日向灘沖に大すべり領域を設定 \\
\hline
\end{tabular}

※本研究での検討ケース

表-2 現行の津波対策(漁港)

\begin{tabular}{|c|c|}
\hline 項 目 & 内 \\
\hline ハード対策 & $\begin{array}{l}\text { ·防潮門扉確実閉鎖のためのマニュアル促進 } \\
\text { ·高潮対策等による防潮堤整備の促進 } \\
\text { ·高潮対策等によるる防潮堤整備の促進 } \\
\text { ·高潮対策等による防潮堤整備の促進 } \\
\text { ·海岸防潮堤総点検結果に基づく耐津波補強 }\end{array}$ \\
\hline ソフト対策 & $\begin{array}{l}\text { ·各市町との連携に拈ける防潮門扉閉鎖訓練の実施 } \\
\cdot \text { 市町津波災害対応マニュアル整備の促進 } \\
\text { ·避難訓練の実施 } \\
\text { ·住民への意識啓発 }\end{array}$ \\
\hline
\end{tabular}

表-3 当面の津波対策(漁港)

\begin{tabular}{|c|c|}
\hline 項 目 & 内 \\
\hline ハード対策 & $\begin{array}{l}\text { ·防潮堤等未整備箇所の前倒し整備 } \\
\text { ·既存施設強化対策 } \\
\text { ·【緊】沼島に扮ける避難路の整備 } \\
\text { ·【緊】排機場の耐震・津波浸水対策 } \\
\text { ·【緊】液状化対策 } \\
\text { ·【緊】老朽化した構造物の撤去 }\end{array}$ \\
\hline ソフト対策 & $\begin{array}{l}\text { ·津波シミュレーションの実施 } \\
\text { ·避難訓練等の実施 } \\
\text { ・広域的な避難場所確保に関する調整 } \\
\text { ·通報・通信手段の多様化 }\end{array}$ \\
\hline
\end{tabular}

※【緊】：緊急防災・減災対策事業（兵庫県）

シュでの計算值を抽出し, 淡路島沿岸に到達する津波の 特性 (高さ, 海底地盤高の隆起量), 被害予想 (浸水深), 避難や沖出し猶予時間について検討した.

\section{3. 調査結果}

\section{（1）ヒアリング調査}

\section{a) 漁港における津波対策}

兵庫県庁および淡路県民局漁港課においてヒアリング 調査（2012年8月3日・7日）を実施した。中央防災会議 の専門調査会による，南海トラフ巨大地震における本格 的な津波被害想定が出されるまでには, 今後1年程度の 時間が必要になるということで，当時の県においては,
表-4 現行の津波対策(港湾)

\begin{tabular}{|c|c|}
\hline 項 目 & 内 \\
\hline ハード対策 & $\begin{array}{l}\cdot \text { 防潮堤の整備 } \\
\cdot \text { 水門·陸閘の整備 } \\
\cdot \text { 水門·陸閘などの電動化, 遠隔操作化 }\end{array}$ \\
\hline ソフト対策 & $\begin{array}{l}\text { ·情報伝達装置の整備 } \\
\cdot \text { 防災学習による意識啓発 } \\
\text { •防災訓練の実施 }\end{array}$ \\
\hline
\end{tabular}

表-5 当面の津波対策(港湾)

\begin{tabular}{c|l}
\hline 項 目 & \multicolumn{1}{|c}{ 内 容 } \\
\hline ハード対策 & $・$ 防潮施設の整備 \\
\hline ソフト対策 & ・防災学習による意識啓発 \\
& $\cdot$ 防災訓諌の実施 \\
\hline
\end{tabular}

現行の津波想定高の2倍を津波高とし，当面の津波対策 を行うこととしていた。 その内容は, 国から補助を受け て行う事業と, 県単独費で行う緊急防災・減災対策事業 の2つの事業に区分される。

表-2に現行の津波対策, 表-3にハード・ソフト両面に おける当面の津波対策を示す.

現行の津波対策のうち防潮門屝については，2010年2 月のチリ地震津波を契機に，確実に閉鎖するためのマ ニュアル整備を行うとともに，各市と連携して閉鎖訓練 を実施してきたほか，防潮堤については高潮対策を前提 とした整備を進めている.これに加え, 電動化・遠隔自 動閉鎖化や，海岸防潮堤総点検結果に基づく耐津波補強 も実施している。一方, ソフト対策となる住民避難につ いては, 市町津波災害対応マニュアル整備の促進, 避難 訓練の実施，住民への意識啓発を行うなどの取り組みを 促進している。

また，当面実施していくべきハード対策としては，今 後5年以内を目途に早期完成を目指す防潮堤等未整備箇 所の前倒し工事や，レベル2相当の津波で越流する区間 の既存防潮堤本体や背後の水吒き部の緊急点検ほか, 排 水機場等の電気・機械設備の高所移設といった機械・電 気設備の先行的な浸水対策を挙げている, なお, 県単独 費により実施する緊急防災・減災対策では, 避難路・避 難場所の確保, 排水機場の耐震化等を図る漁港海岸排水 機場整備, 漁港関連用地（県有地）の液状化対策, 地震 時の崩落によって避難に支障をきたすと考えられる老朽 化した漁港関連建築物の撤去といった4つの事業を実施 している。

一方，当面実施すべきソフト対策としては，暫定的な 浸水想定区域図・警戒区域図作成のための津波シミュ レーションの実施, 市や住民と連携した合同防災訓練や 防潮門扉閉鎖の実施，一時避難ビルの増加に向けた取り 組みを行うほか, 広域的な避難場所の確保や, エリア 


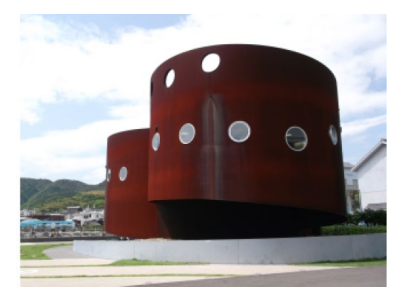

写真-1 福良港津波防災ステーション

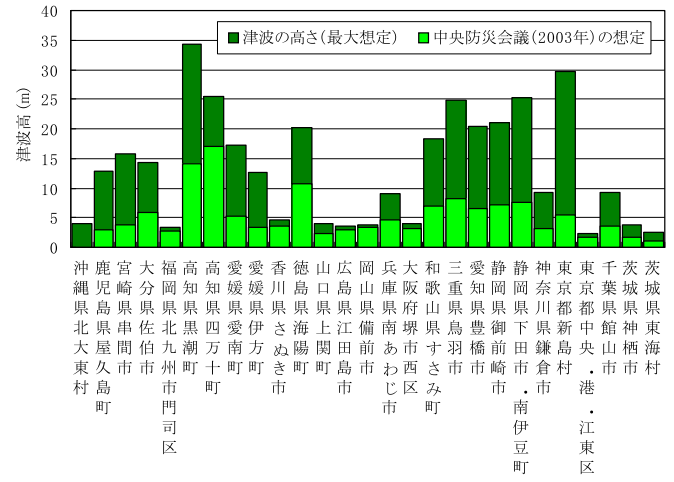

図-2 想定の見直し前後の津波高さ

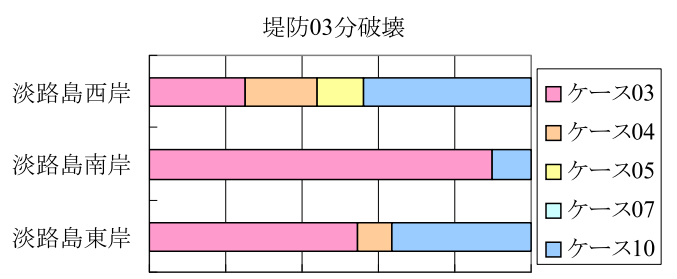

$\begin{array}{llllll}0 \% & 20 \% & 40 \% & 60 \% & 80 \% & 100 \%\end{array}$

堤防破堤

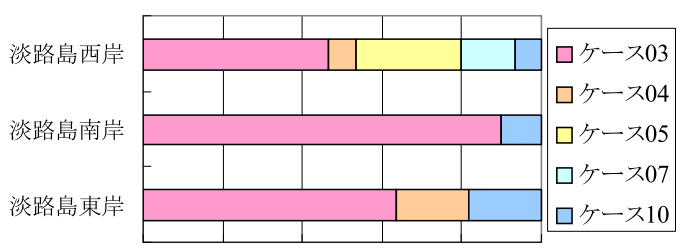

$\begin{array}{llllll}0 \% & 20 \% & 40 \% & 60 \% & 80 \% & 100 \%\end{array}$

図-3 最大浸水深をもたらす計算ケースの内訳

メール活用等の情報伝達のための手段を多様化させるこ とで情報伝達体制を充実させることなどを挙げている.

\section{b）港湾における津波対策}

洲本土木事務所港湾課においてヒアリング調查（2012 年8月7日）を実施した。表-4に現行の津波対策，表-5に ハード・ソフト両面に打ける当面の津波対策を示す. 1946年12月21日に発生した昭和南海地震津波では, 地震 の規模が比較的小さく，幸いにも島内での死者はゼロで あったが，住宅の過密化と老朽化，住民の高齢化によっ て, 次の南海トラフ巨大地震では大きな被害が出ること
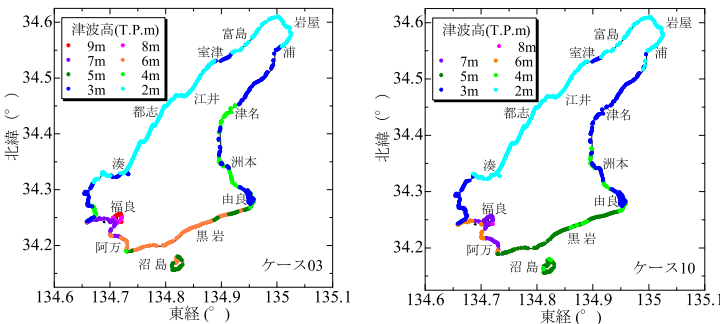

図-4予想津波高さ(ケース03とケース10)
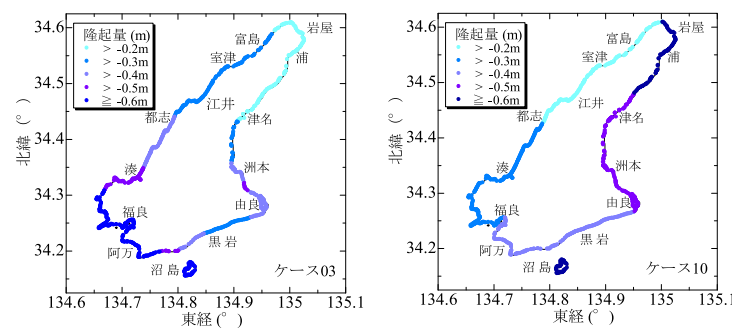

図-5 海岸線地盤高の隆起量(ケース03とケース10)

が懸念される.

兵庫県では，淡路島に扔ける港湾の津波対策において は南あわじ市・福良港に最も力を入れている，同島での 海岸施設の整備率は7割程度に留まっており, 県では従 来通り高潮対策事業をべースとした防潮堤の整備を進め るとともに, 水門・陸閘の整備, 電動化, 遠隔操作化や, 津波情報の迅速な伝達のための情報伝達装置の整備等の ハード対策を進めている，なお，淡路島沿岸では第二室 戸台風で損傷を受けた護岸が侵食によって陥没する事例 が随所に見られており，既に整備した護岸を再点検し， 劣化した筒所を健全な状態に戻すといった事業も進めら れている。

また，福良地区では，津波防災に対する啓蒙と避難施 設として，(1)備える，(2)伝える，(3)逃げる，(4)学ぶ の4 つの役割を有した「福良港津波防災ステーション」 （写真-1）を2010年9月に整備した。図-2に示すとおり， 同地区での当初（2003年）の予想津波高さは4.7mであり， 同施設の避難スペースの標高（T.P.+6.6m）は十分であっ たが，今回の見直しによって $9 m$ もの津波の到達が予想さ れることとなり，同地区においては新たな避難場所の策 定と避難経路の確保が課題となっている.

なお，港湾でのソフト対策としては防災学習による意 識啓発や防災訓練等が実施されている。

\section{(2) データ解析}

\section{a) 淡路島沿岸に被害をもたらす想定ケース}

内閣府中央防災会議モデル検討会の各計算ケースでの 計算結果（浸水深）のうち，淡路島海岸線に該当する メッシュ（最小メッシュ間隔 $10 \mathrm{~m} ）$ の浸水深デー夕を抽 出し, 最も浸水深が大きくなる計算ケースを沿岸区域 

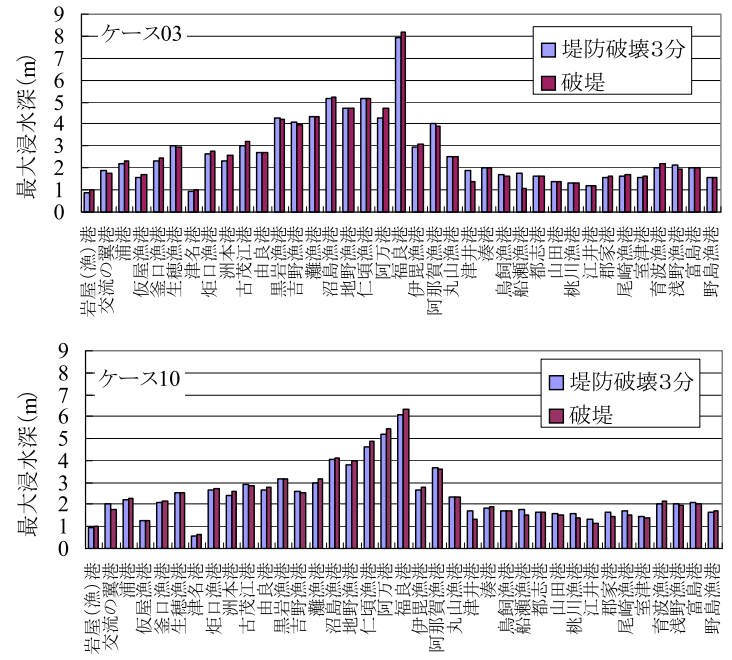

図-6 最大浸水深(ケース03とケース 10$)$
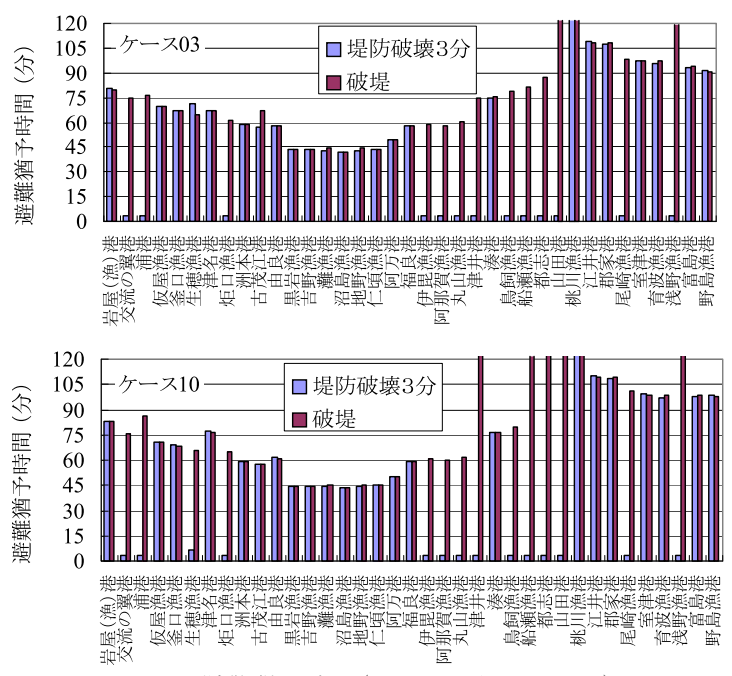

図-7 避難猶予時間(ケース03とケース 10$)$

基づいて島内一律に行われるのではなく，個々の最悪シ ナリオを検討することの必要性を示唆している.

\section{b) 予想津波高と海岸線地盤高の隆起量の空間分布}

ここでは, 紙面の都合上, 淡路島沿岸に大きな被害を もたらすケース03とケース10の場合について取り上げ る. 図-4に予想津波高さ, 図-5に海岸線地盤高の隆起量 の空間分布をそれぞれ示す. 図-4に示す予想津波高さに ついてみると, 両ケースで結果が大きく異なる沿岸区域 は, 淡路島南岸であり, 特に沼島に扔いて, ケース03で 津波発生源に直接面していない北岸での津波高さが増大 していることに注意が必要である，最も高い津波が寄せ るのは, 南あわじ市の福良港で, 最大 $9 \mathrm{~m}$ なっている. 前節に記したと抢り，同地区に打いては既存ハード対策 の見直しと避難路・避難場所の拡充等のソフト対策の充
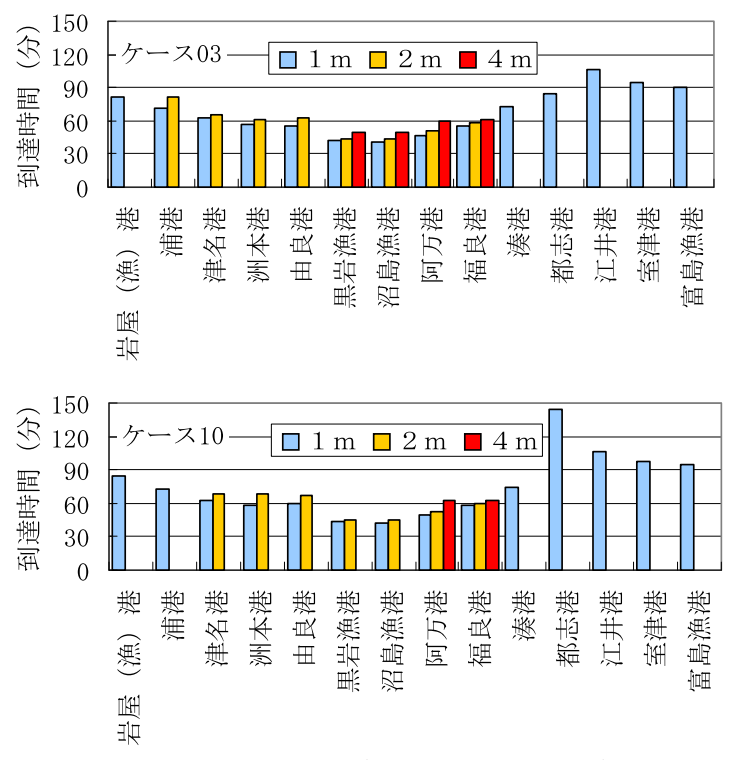

図-8 津波到達時間(ケース03とケース10)

実が喫緊の課題である.

一方, 図-5に示す海岸線の地盤高を見ると, ケース03 ともに沿岸全域で沈下する結果となっている。 各漁港・ 港湾に押いては, 堤防の強化・嵩上げ等の既存施設の改 良が必要であるとともに，こうした沈下量を踏まえた上 での防災・減災計画の策定が求められる。

\section{c) 最大浸水深と避難猶予時間の比較}

図-6にケース03とケース10での各漁港・港湾における 最大浸水深, 図-7に避難猶予時間（地震発生～浸水深 $30 \mathrm{~cm}$ までの時間）を示す。ここでの避難猶予時間につい ては, 須賀ら（1995）の実験結果を参考に, 当該メッ シュの浸水深が $30 \mathrm{~cm}$ に達するまでの時間とした，なお， 浸水深 $30 \mathrm{~cm}$ は老人や子どもが安全に歩行できる限界の水 深とされている. 図-6より, 地震発生から3分後に堤防が 破壊されるとした場合と破堤した場合ともに, ケース03 とケース10のいずれの場合においても最大浸水深に大き な差異は見られない。これに対し，避難猶予時間につい ては, 図-7に示すとおり，場所によって明確な差異が見 られた. すなわち堤防は破堤しても破壞に至らなければ, 避難時間を十分に稼ぐことが可能となり, 粘り強い構造 物とすることの重要性が示された。

\section{d）船舶沖出しの可能性についての検討}

2003年十勝沖地震（たとえば, 田中ら，2004）や2011 年東北地方太平洋沖地震（たとえば, 片田ら, 2012）で は. 沖出しによって船舶が津波被害を免れた事例が報告 されている，一方でタイミングを逃せば，人命に関わる だけに, 沖出しについてのルール策定は重要な課題であ る.ここでは, 南海トラフ巨大地震発生時の沖出し可能 


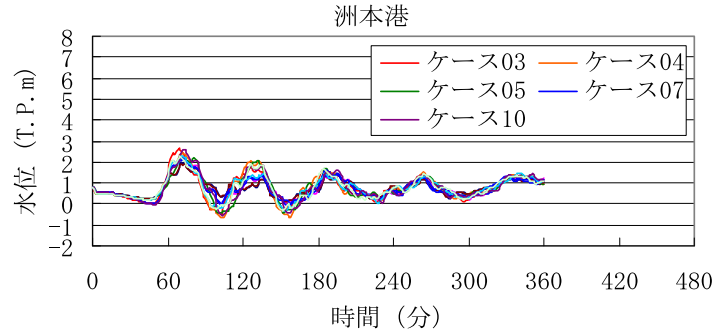

江井港

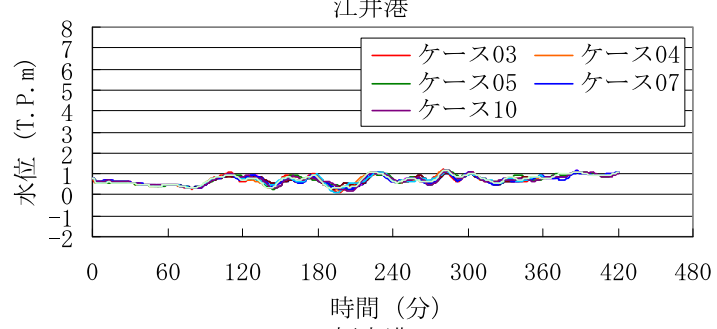

福良港

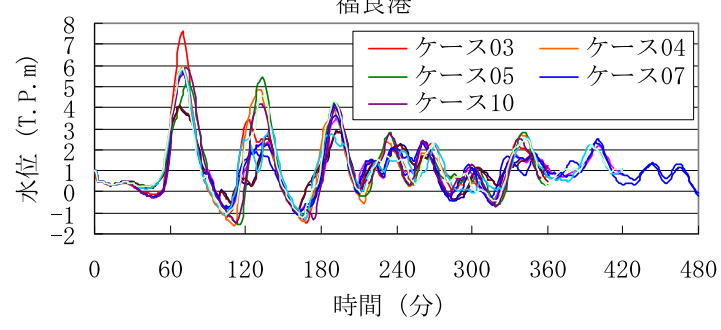

図-9 海域別津波波形

性について検討を行った，図-8にケース03とケース10の 場合に扮ける高さ別の津波到達時間を示す，高さ4mを超 える津波が1時間以内に到達する島南部の漁港・港湾に おいては，船の沖出しは原則控えるべきであるといえる. 一方，高さ1mの津波の到達に80分以上要する東岸や西岸 の漁港・港湾に执いてはその限りではなく, 沖出しの導 入を減災計画の視野に入れることが可能である.しかし， その場合でも，たとえば，風間ら（2006）や村澤ら（2009） の提案にならい, 危険な状況下で船舶避難を回避するため の細やかな避難ルールの構築が不可欠である.

\section{e) 養殖業への影響}

養殖は，湾や入り江等の静穏な海域にいかだや生筫等 を設置して営まれるものであり，波浪の影響を強く受け ない海域での操業を前提とするため，一般的に津波に対 して脆弱である. 2011年東北地方太平洋沖地震の際にも, 震源より遠く離れた四国沖でカンパチ等の養殖業に被害 が出た（青野，2011）との報告ある. 図-9に海域別に各 ケースでの到達津波の波形を示す。比較的静穏と予想さ れる島西岸に位置する江井港は, 洲本港や福良港と比較
して波高こそ低いものの継続時間が長くなっており，周 辺海域での養殖業への影響が懸念される。

\section{4. まとめ}

本研究では, 近い将来に発生するとされる南海トラフ 巨大地震津波に対する淡路島の漁港・港湾の津波対策の 現状と課題をヒアリング調査により明らかにした。また， 内閣府中央防災会議のモデル検討会による試算結果を漁 港・港湾レベルで出力し, 淡路島沿岸に到達する津波の 特性 (高さ, 海底地盤高の隆起量), 被害予想 (浸水深), 避難や沖出し猶予時間について検討した.

一連の解析結果は, ヒアリング調査で示された課題解 決に向けての施策の優先順位等を判断する際に有用であ る. 特に, シナリオによって異なる結果が得られた事項 （たとえば，避難猶予時間や船舶の沖出し可能性）につ いては，全島一律の対応でなく，より細かい海域区分レ ベル等での対応が必要である.

\section{参 考 文 献}

青野怜史 (2011)：高知県須崎市野見湾に损けるカンパチ養殖 業の津波被害状況，日本水産学会誌，第77巻，No.6, pp.1106-1107.

風間隆宏 $\cdot$ 中村 隆 - 伊藤敏朗 $\cdot$ 大塚浩二 $\cdot$ 佐藤勝弘 $\cdot$ 今津 雄吾 (2006)：津波による船舶被害軽減のための避難海域 に関する検討，海岸工学論文集，第53卷，pp.1356-1360.

片田敏孝・村澤直樹 - 金井昌信 (2012)：漁船の津波沖出し行 動に関するルール策定効果の検証 -2011 年東北地方太平 洋沖地震津波襲来時の根室市落石漁協の対応を事例に一, 災害情報, No.10, pp.103-112.

須賀堯三・上坂恒雄，吉田高樹・浜口憲一郎・陳 志軒 (1995) : 水害時の安全避難行動（水中歩行）に関する検討, 水工 学論文集, 第39卷, pp. 879-882.

田中亮平・河田惠昭 - 井上雅夫 - 原田賢治 - 高橋智幸 (2004) : 2003年十勝沖地震時における漁民の避難行動に関する実 態調查, 海岸工学論文集, 第51巻, pp.1301-1305.

内閣府 (2012a)：南海トラフ巨大地震の被害想定について（第 二次報告), http://www.bousai.go.jp/jishin/nankai/taisaku_wg/ index.htm（2014 年 5 月 1 日確認).

内閣府 (2012b) : 南海トラフの巨大地震に関する津波高、浸水 域、被害想定の公表について, http://www.bousai.go.jp/jishin/nankai/nankaitrough_info.html (2014 年 5 月 1 日確認).

兵庫県 (2012) : 平成23年兵庫県港湾統計年報, pp.i-ii.

兵庫県 (2013a) : 指定漁港一覧, http://web.pref.hyogo.lg.jp/af19/af19_000000003.html (2014 年 5 月 1 日確認)

兵庫県 (2013b) : 県下の漁業協同組合について, https://web.pref.hyogo.lg.jp/af18/af18_000000011.htm (2014 年 5 月 1 日確認)

村澤直樹 - 片田敏孝・高柳省一・岩佐雅教・松下圭吾 (2009)： 津波襲来時に扔ける漁民の避難対応に関する研究，土木 計画学研究講演論文集, vol.39, CD-ROM (269). 